\title{
The Diversity of Hoya (Apocynaceae: Asclepiadoideae) in Some Parts of Kedah and Perak, Peninsular Malaysia
}

\author{
Azim Rabbani', Zakaria Rahmad ${ }^{1 *}$, Rusly Rosazlina', Gbenga Akomolafe ${ }^{1,2}$, \\ Syed Mohd Edzham ${ }^{1}$ and Faizal Azmi ${ }^{1}$ \\ ${ }^{1}$ School of Biological Sciences, Universiti Sains Malaysia, 11800, Penang, Malaysia \\ ${ }^{2}$ Department of Plant Science and Biotechnology, Federal University of Lafia, PMB 146, \\ Lafia, Nasarawa State, Nigeria
}

\begin{abstract}
This study provided data on the diversity of Hoya species reported to occur in some parts of the northern region of Peninsular Malaysia. Seven locations were chosen between two states, Kedah (Lata Celak, Sedim, and Bukit Hijau) and Perak (Mahang, Belukar Semang, Sungai Rui, and Pondok Tanjung). This extensive fieldwork was carried out from 2018 until the end of 2019 to provide a baseline checklist for this genus in this northern region. All living specimens found were recorded, and some species were cultivated for further identification and ex-situ conservation purposes. A total of 27 species and one variety were recorded, out of which 15 species were newly reported for the northern region of Peninsular Malaysia. The newly described species, Hoya peninsularis Rodda \& Zakaria, was also reported in this study. One unknown species was found and labelled as Hoya sp. cf. scortechinii. Further identification process together with molecular analysis of this plant is still ongoing. The most diverse forests are Sungai Rui and Lata Celak, having the Shannon index of 2.741 and 2.622, respectively. Both forests possess the richest in Hoya species, but with low dominance index. The Sorenson similarity index is $6.74 \%$, indicating a very low similarity of Hoya species between the studied sites. Due to the high diversity recorded, the number of Hoya species in the

ARTICLE INFO

Article history:

Received: 31 August 2020

Accepted: 10 November 2020

Published: 24 February 2021

DOI: https://doi.org/10.47836/pjtas.44.1.11

$\overline{\text { E-mail addresses: }}$

azimrabbani@rocketmail.com (Azim Rabbani)

rahmadz@usm.my (Zakaria Rahmad)

rosazlinarusly@usm.my (Rusly Rosazlina)

gfakomolafe@yahoo.com (Gbenga Akomolafe)

edzham@usm.my (Syed Mohd Edzham)

faizalazmi@gmail.com (Faizal Azmi) country is expected to increase if the genus is explored continuously. However, most of the study areas were exposed to extreme logging activities and had a high degree of human disturbances, indicating the need for intensive conservation efforts in this genus.

Keywords: Checklist, conservation, diversity, Hoya, northern region, Peninsular Malaysia
\end{abstract}

* Corresponding author 


\section{INTRODUCTION}

The epiphytic genus Hoya $\mathrm{R}$. Br. is one of the most species-rich genera of the tribe Marsdenieae of Asclepiadoideae (Apocynaceae). This genus includes 350450 currently accepted species found throughout the tropics and sub-tropics regions of Asia and Australia (Lamb \& Rodda, 2016). Some of the species of this genus are still being newly discovered and described, particularly from the Malaysian part of Borneo Island (Rodda, 2015). In Peninsular Malaysia, Hoya has been revised three times (Rodda \& Simonsson, 2013). This includes 23 species by King and Gamble (1908), 25 species by Ridley (1923), and 25 species by Rintz (1978). Other revisions that were published later reported 27 species of Hoya (Kiew, 1989; Rodda \& Simonsson, 2012). However, a recent study proved that numerous species could be discovered by searching through the available herbarium specimens (Salim \& Nikong, 2020).

Hoya species are lactiferous epiphytic lianas mostly characterised as having milky saps. They are commonly known as waxy plants due to the waxy appearance of their leaves and flowers. Hoyas are evergreen plants whose leaves are positioned oppositely on each node, and the leaf shapes vary from orbicular to linear (Kleijn \& van Donkelaar, 2001; Wanntorp, 2009). They have unusual floral morphology, i.e. extraaxillary umbelliform inflorescence and star-shaped corona. This makes Hoya plants popular ornamentals (Wanntorp \& Kunze, 2009). Generally, hoyas can be found in places with high humidity and good sunlight exposures (Hansen et al., 2007; Rahayu et al., 2018; Rintz, 1980). These climbers can be seen along the rivers and streams, and usually occupy the lower canopy of forests (Rahayu et al., 2010).

Usually, to maximise exposure to sunlight, Hoya species use the big trees as host plants. The host plants have rough and notched bark textures that accumulate humus and litter, thereby facilitating the growth of Hoya species (Sulaeman et al., 2019). Many of the epiphytes are associated with arboreal ants (Davidson \& Epstein, 1989). Therefore, Hoya plants are known as myrmecophytes or called as ant-plants (Kleijn \& van Donkelaar, 2001; Orivel \& Leroy, 2011). They usually provide shelter and food for these types of ants. In return, these ants build carton nests that contain organic materials for the plants as nutrients (Corbara et al., 1999). The presence of these ants can also promote seed dispersal (Wagner, 1997).

Hoyas are not only recognised for the beauty of their flowers, but are also plants with several uses such as pollutantabsorbers (Yang et al., 2009). They are also known as sources of certain medicinal and pharmaceutical compounds (Barukial \& Sarmah, 2011; Gautam et al., 2013; Mollik et al., 2010). Based on Wanntorp et al. (2006), new species of Hoya are added each year. However, the most common threat faced by hoyas is habitat degradation. Clearing of the host plants has threatened Hoya populations and may lead to the extinction of species. The hoyas are rarely found blooming in the 
wild. Therefore, continuous visits to similar sites are often required to ensure recording and collecting plants in bloom.

This study aimed to develop an inventory of Hoya species found in certain parts of the northern region of Peninsular Malaysia. Previous studies (Kiew, 1989; Rintz, 1978; Rodda \& Simonsson, 2012) were mostly focused on central and eastern parts of the peninsular. Thus, it is essential to have an adequate understanding of the presence, conservation status, and ecological role of Hoya species in the forest by conducting the quantitative monitoring of its diversity.

\section{MATERIALS AND METHODS}

The sampling of Hoya species was conducted from January 2018 until December 2019. The sampling was focused on some parts of the northern region of Peninsular Malaysia (Kedah and Perak). Seven study sites were chosen between the two states, involving rivers or streams that were easily accessible and containing good habitats for hoyas (Table 1). The fieldwork was focused on areas near streams and lower canopy, as hoyas prefer to occupy areas with high humidity and good exposure to sunlight.
Each of the sampling sites was accessed multiple times to maximise the finding. Modified line transect method was used for the sampling. A line transect of 1,000 meters was set at each site along the river bank as the primary reference route. The specimens of hoyas were collected and identified to the lowest taxa using the taxonomic keys (Lamb \& Rodda, 2016; Rintz, 1978). The identification process was made easier by one of the authors, who was a taxonomist and Hoya specialist.

Digital images of the whole plants or parts of it that were available at the collection time were also obtained to facilitate species identification. The plants without flowers and difficult to identify were grown ex-situ at Universiti Sains Malaysia (USM) plant nursery. Voucher specimens were deposited at the Herbarium Unit, USM.

The PAST 4.0 software (Hammer et al., 2001) was used to quantify the diversity indices, including Shannon index, Simpson index, and species evenness. A non-parametric rarefaction and extrapolation analysis with 500 bootstrap replicates was used to estimate the species richness of Hoya at the sampled sites (Chao et al., 2016). This

Table 1

List of study sites

\begin{tabular}{|c|c|c|c|}
\hline Study sites & Type & Gps coordinate & Altitude (m) \\
\hline Lata Celak, Kedah & Lowland dipterocarp & $5^{\circ} 34^{\prime} \mathrm{N} 100^{\circ} 51^{\prime} \mathrm{E}$ & $200-300$ \\
\hline Sedim, Kedah & Lowland dipterocarp & $5^{\circ} 24^{\prime} \mathrm{N} 100^{\circ} 46^{\prime} \mathrm{E}$ & $200-300$ \\
\hline Bukit Hijau, Kedah & Lowland dipterocarp & $5^{\circ} 30^{\prime} \mathrm{N} 100^{\circ} 46^{\prime} \mathrm{E}$ & $200-300$ \\
\hline Mahang, Perak & Hill dipterocarp & $5^{\circ} 19^{\prime} \mathrm{N} 100^{\circ} 45^{\prime} \mathrm{E}$ & $450-800$ \\
\hline Belukar Semang, Perak & Lowland dipterocarp & $5^{\circ} 34^{\prime} \mathrm{N} 100^{\circ} 59^{\prime} \mathrm{E}$ & $200-300$ \\
\hline Sungai Rui, Perak & Lowland dipterocarp & $5^{\circ} 26^{\prime} \mathrm{N} 101^{\circ} 06^{\prime} \mathrm{E}$ & $200-300$ \\
\hline Pondok Tanjung, Perak & Peat swamp forest & $4^{\circ} 59^{\prime} \mathrm{N} 100^{\circ} 43^{\prime} \mathrm{E}$ & $100-200$ \\
\hline
\end{tabular}


analysis was based on avoiding the bias that involved species with only single individuals at any of the sites. The confidence intervals of the species curves were used to determine the significant differences in the species richness between the sites. This analysis was done using iNEXT online software (Chao et al., 2016). The Sorenson similarity index was determined to assess the similarities in the species between the sampled sites, using the equation below:

$$
S c=(2 W / a) \times 100 \%(\text { Sorenson, } 1948)
$$

where $S c$ is the similarity coefficient, $W$ represents the number of species common to all sites, and $a$ means the sum of all the number of species observed at each of the study sites.

\section{RESULTS AND DISCUSSION}

A total of 784 Hoya plants were recorded from the seven study sites, which consist of 27 species and one variety (Table 2). Earlier researchers recorded 27 species of Hoya in Peninsular Malaysia (Kiew, 1989; Rintz, 1978; Rodda \& Simonsson, 2012), and this study recorded $89 \%$ of them in the sampling areas. From this study, 15 taxa were newly reported for the northern region of Peninsular Malaysia. They include Hoya beccarii, Hoya coronaria, Hoya diversifolia, Hoya elliptica, Hoya erythrina, Hoya erysthrostemma, Hoya flagellata, Hoya forbesii, Hoya ignorata, Hoya javanica, Hoya lasiantha, Hoya mitrata, Hoya parviflora, Hoya verticillata, and Hoya verticillata var. hendersonii. The newly described species, Hoya peninsularis Rodda \& Zakaria (Rodda \& Zakaria, 2020) was also found in this study (Figure 1). This species has been long confused with Hoya finlaysonii due to their similar leaf morphology. One unknown species was found in this study and was labelled as Hoya sp. cf. scortechinii (Figure 2). It has similar inflorescences with Hoya scortechinii but differs in colour and the leaves. Further identification process with the aid of molecular analysis is still ongoing to clarify the status of this particular species. H. ignorata (Figure 3), which was recently rediscovered in Terengganu (Salim \& Nikong, 2020), as this species was previously reported by Corner in 1934 at Kemaman, Terengganu (Trân et al., 2011) was also found in three different sites. The most common and abundantly distributed species from all the study sites is Hoya revoluta (101; Figure 4), followed by $H$. finlaysonii (81; Figure 5). Both species were found to adapt to a vast range of environmental parameters and are distributed at different levels of altitude.

A few uncommon species with fewer individuals such as Hoya curtisii (1), H. flagellata (2), Hoya mappigera (2), $H$. verticillata var. hendersonii (2), and Hoya imperialis (3) were observed. This result suggests that a broader collection effort should be conducted in the future to update the record of Hoya by focusing on the selected forests around Kedah and Perlis. It is observed that a few species, namely $H$. ignorata, $H$. imperialis, and $H$. mappigera, which are also found in some 
Table 2

List of Hoya species found at each of the study sites

\begin{tabular}{|c|c|c|c|c|c|c|c|c|}
\hline \multirow[b]{2}{*}{$\mathrm{S} / \mathrm{N}$} & \multirow[b]{2}{*}{ Name of species } & \multicolumn{7}{|c|}{ Study sites } \\
\hline & & $\begin{array}{c}\text { Lata } \\
\text { Celak }\end{array}$ & Sedim & $\begin{array}{l}\text { Bukit } \\
\text { Hijau }\end{array}$ & Mahang & $\begin{array}{l}\text { Belukar } \\
\text { Semang }\end{array}$ & $\begin{array}{l}\text { Sungai } \\
\text { Rui }\end{array}$ & $\begin{array}{l}\text { Pondok } \\
\text { Tanjung }\end{array}$ \\
\hline 1 & $\begin{array}{l}\text { Hoya beccarii Rodda } \\
\text { \& Simonsson (voucher: } \\
\text { RZ/19/021) }\end{array}$ & $\sqrt{ }$ & $\mathrm{x}$ & $\mathrm{x}$ & $\mathrm{x}$ & $\sqrt{ }$ & $\sqrt{ }$ & $\mathrm{x}$ \\
\hline 2 & $\begin{array}{l}\text { Hoya caudata Hook. f. } \\
\text { (voucher: RZ/19/036) }\end{array}$ & $\sqrt{ }$ & $\sqrt{ }$ & $\sqrt{ }$ & $\sqrt{ }$ & $\sqrt{ }$ & $\sqrt{ }$ & $\sqrt{ }$ \\
\hline 3 & $\begin{array}{l}\text { Hoya coriacea Blume } \\
\text { (voucher: RZ/18/016) }\end{array}$ & $\sqrt{ }$ & $\mathrm{x}$ & $\mathrm{x}$ & $\sqrt{ }$ & $\mathrm{x}$ & $\sqrt{ }$ & $\sqrt{ }$ \\
\hline 4 & $\begin{array}{l}\text { Hoya coronaria Blume } \\
\text { (voucher: RZ/19/033) }\end{array}$ & $\sqrt{ }$ & $\mathrm{x}$ & $\mathrm{x}$ & $\mathrm{x}$ & $\sqrt{ }$ & $\sqrt{ }$ & $\sqrt{ }$ \\
\hline 5 & $\begin{array}{l}\text { Hoya curtisii King \& } \\
\text { Gamble } \\
\text { (voucher: RZ/19/032) }\end{array}$ & $\sqrt{ }$ & $\mathrm{x}$ & $\mathrm{x}$ & $\mathrm{x}$ & $\mathrm{x}$ & $\mathrm{x}$ & $\mathrm{x}$ \\
\hline 6 & $\begin{array}{l}\text { Hoya diversifolia } \text { Blume } \\
\text { (voucher: } \mathrm{RZ} / 18 / 008 \text { ) }\end{array}$ & $\sqrt{ }$ & $\mathrm{x}$ & $\mathrm{x}$ & $\mathrm{x}$ & $\mathrm{x}$ & $\mathrm{x}$ & $\sqrt{ }$ \\
\hline 7 & $\begin{array}{l}\text { Hoya elliptica Hook. f. } \\
\text { (voucher: RZ/18/005) }\end{array}$ & $\sqrt{ }$ & $\sqrt{ }$ & $\sqrt{ }$ & $\mathrm{x}$ & $\sqrt{ }$ & $\sqrt{ }$ & $\sqrt{ }$ \\
\hline 8 & $\begin{array}{l}\text { Hoya erythrina Rintz } \\
\text { (voucher: RZ/19/031) }\end{array}$ & $\sqrt{ }$ & $\mathrm{x}$ & $\mathrm{x}$ & $\mathrm{x}$ & $\sqrt{ }$ & $\sqrt{ }$ & $\sqrt{ }$ \\
\hline 9 & $\begin{array}{l}\text { Hoya erysthrostemma Kerr } \\
\text { (voucher: RZ/18/011) }\end{array}$ & $\mathrm{x}$ & $\mathrm{x}$ & $\mathrm{x}$ & $\mathrm{x}$ & $\mathrm{x}$ & $\sqrt{ }$ & $\mathrm{x}$ \\
\hline 10 & $\begin{array}{l}\text { Hoya finlaysonii Wight } \\
\text { (voucher: RZ/18/019) }\end{array}$ & $\sqrt{ }$ & $\mathrm{x}$ & $\sqrt{ }$ & $\sqrt{ }$ & $\sqrt{ }$ & $\sqrt{ }$ & $\sqrt{ }$ \\
\hline 11 & $\begin{array}{l}\text { Hoya flagellata Kerr } \\
\text { (voucher: RZ/19/035) }\end{array}$ & $\sqrt{ }$ & $\sqrt{ }$ & $\mathrm{x}$ & $\mathrm{x}$ & $\mathrm{x}$ & $\mathrm{x}$ & $\mathrm{x}$ \\
\hline 12 & $\begin{array}{l}\text { Hoya forbesii King \& } \\
\text { Gamble } \\
\text { (voucher: RZ/18/012) }\end{array}$ & $\sqrt{ }$ & $\sqrt{ }$ & $\sqrt{ }$ & $\sqrt{ }$ & $\sqrt{ }$ & $\sqrt{ }$ & $\sqrt{ }$ \\
\hline 13 & $\begin{array}{l}\text { Hoya ignorata T. B. Tran, } \\
\text { Rodda, Simonsson \& } \\
\text { Jongku Lee } \\
\text { (voucher: RZ/19/036) }\end{array}$ & $\sqrt{ }$ & $\mathrm{x}$ & $\mathrm{x}$ & $\sqrt{ }$ & $\mathrm{x}$ & $\sqrt{ }$ & $\mathrm{x}$ \\
\hline 14 & $\begin{array}{l}\text { Hoya imperialis Lindl. } \\
\text { (voucher: RZ/19/026) }\end{array}$ & $\mathrm{x}$ & $\mathrm{x}$ & $\mathrm{x}$ & $\mathrm{x}$ & $\mathrm{x}$ & $\sqrt{ }$ & $\mathrm{x}$ \\
\hline 15 & $\begin{array}{l}\text { Hoya javanica Boerl. } \\
\text { (voucher: RZ/18/006) }\end{array}$ & $\sqrt{ }$ & $\mathrm{x}$ & $\mathrm{x}$ & $\sqrt{ }$ & $\mathrm{x}$ & $\sqrt{ }$ & $\mathrm{x}$ \\
\hline 16 & $\begin{array}{l}\text { Hoya lacunosa Blume } \\
\text { (voucher: RZ/18/007) }\end{array}$ & $\sqrt{ }$ & $\mathrm{x}$ & $\mathrm{x}$ & $\mathrm{x}$ & $\sqrt{ }$ & $\sqrt{ }$ & $\sqrt{ }$ \\
\hline 17 & $\begin{array}{l}\text { Hoya lasiantha Korth. ex } \\
\text { Miq. } \\
\text { (voucher: RZ/18/016) }\end{array}$ & $\sqrt{ }$ & $\sqrt{ }$ & $\sqrt{ }$ & $\mathrm{x}$ & $\mathrm{x}$ & $\sqrt{ }$ & $\sqrt{ }$ \\
\hline 18 & $\begin{array}{l}\text { Hoya latifolia } \mathrm{G} \text {. Don } \\
\text { (voucher: RZ/18/27) }\end{array}$ & $\mathrm{x}$ & $\mathrm{x}$ & $\mathrm{X}$ & $\mathrm{x}$ & $\mathrm{x}$ & $\sqrt{ }$ & $\mathrm{x}$ \\
\hline
\end{tabular}


Table 2 (continue)

\begin{tabular}{|c|c|c|c|c|c|c|c|c|}
\hline \multirow[b]{2}{*}{$\mathrm{S} / \mathrm{N}$} & \multirow[b]{2}{*}{ Name of species } & \multicolumn{7}{|c|}{ Study sites } \\
\hline & & $\begin{array}{c}\text { Lata } \\
\text { Celak }\end{array}$ & Sedim & $\begin{array}{l}\text { Bukit } \\
\text { Hijau }\end{array}$ & Mahang & $\begin{array}{l}\text { Belukar } \\
\text { Semang }\end{array}$ & $\begin{array}{l}\text { Sungai } \\
\text { Rui }\end{array}$ & $\begin{array}{l}\text { Pondok } \\
\text { Tanjung }\end{array}$ \\
\hline 19 & $\begin{array}{l}\text { Hoya mappigera Rodda \& } \\
\text { Simonsson } \\
\text { (voucher: RZ/19/024) }\end{array}$ & $\mathrm{x}$ & $\mathrm{x}$ & $\mathrm{x}$ & $\mathrm{x}$ & $\mathrm{x}$ & $\sqrt{ }$ & $\mathrm{x}$ \\
\hline 20 & $\begin{array}{l}\text { Hoya mitrata Kerr } \\
\text { (voucher: RZ/19/020) }\end{array}$ & $\mathrm{x}$ & $\mathrm{x}$ & $\mathrm{x}$ & $\sqrt{ }$ & $\mathrm{x}$ & $\sqrt{ }$ & $\mathrm{x}$ \\
\hline 21 & $\begin{array}{l}\text { Hoya obtusifolia Wight } \\
\text { (voucher: RZ/18/013) }\end{array}$ & $\sqrt{ }$ & $\mathrm{x}$ & $\mathrm{x}$ & $\mathrm{x}$ & $\mathrm{x}$ & $\sqrt{ }$ & $\mathrm{x}$ \\
\hline 22 & $\begin{array}{l}\text { Hoya parviflora Wight } \\
\text { (voucher: RZ/18/009) }\end{array}$ & $\sqrt{ }$ & $\mathrm{x}$ & $\sqrt{ }$ & $\mathrm{x}$ & $\sqrt{ }$ & $\sqrt{ }$ & $\mathrm{x}$ \\
\hline 23 & $\begin{array}{l}\text { Hoya revoluta Wight ex } \\
\text { Hook. f. } \\
\text { (voucher: RZ/18/006) }\end{array}$ & $\sqrt{ }$ & $\sqrt{ }$ & $\sqrt{ }$ & $\sqrt{ }$ & $\sqrt{ }$ & $\sqrt{ }$ & $\sqrt{ }$ \\
\hline 24 & $\begin{array}{l}\text { Hoya scortechinii King \& } \\
\text { Gamble } \\
\text { (voucher: RZ/18/003) }\end{array}$ & $\mathrm{x}$ & $\sqrt{ }$ & $\mathrm{x}$ & $\sqrt{ }$ & $\mathrm{x}$ & $\mathrm{x}$ & $\mathrm{x}$ \\
\hline 25 & $\begin{array}{l}\text { Hoya verticillata (Vahl) } \\
\text { G. Don } \\
\text { (voucher: RZ/18/017) }\end{array}$ & $\mathrm{x}$ & $\sqrt{ }$ & $\sqrt{ }$ & $\sqrt{ }$ & $\mathrm{x}$ & $\sqrt{ }$ & $\mathrm{x}$ \\
\hline 26 & $\begin{array}{l}\text { Hoya verticillata (Vahl) } \\
\text { G. Don var. hendersonii } \\
\text { (Kiew) Veldkamp } \\
\text { (voucher: RZ/18/015) }\end{array}$ & $\sqrt{ }$ & $\mathrm{x}$ & $\mathrm{x}$ & $\mathrm{x}$ & $\mathrm{x}$ & $\mathrm{x}$ & $\mathrm{x}$ \\
\hline 27 & $\begin{array}{l}\text { Hoya peninsularis } \\
\text { Rodda \& Zakaria } \\
\text { (voucher: RZ/19/29) }\end{array}$ & $\mathrm{x}$ & $\mathrm{x}$ & $\mathrm{x}$ & $\mathrm{x}$ & $\mathrm{x}$ & $\mathrm{x}$ & $\sqrt{ }$ \\
\hline 28 & $\begin{array}{l}\text { Hoya sp. cf. scortechinii } \\
\text { (voucher: RZ/19/038) }\end{array}$ & $\mathrm{x}$ & $\mathrm{x}$ & $\mathrm{x}$ & $\mathrm{x}$ & $\mathrm{x}$ & $\mathrm{x}$ & $\sqrt{ }$ \\
\hline
\end{tabular}

Note. $\sqrt{ }$ means present, $\mathrm{x}$ means absent

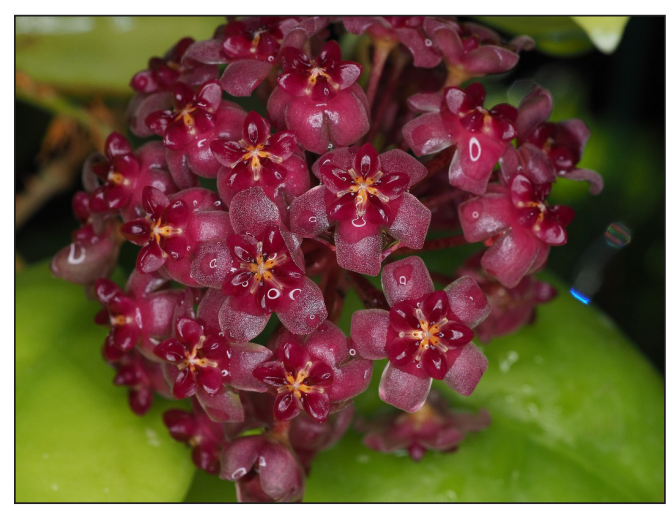

Figure 1. The inflorescence of Hoya sp. cf. scortechinii at the study sites

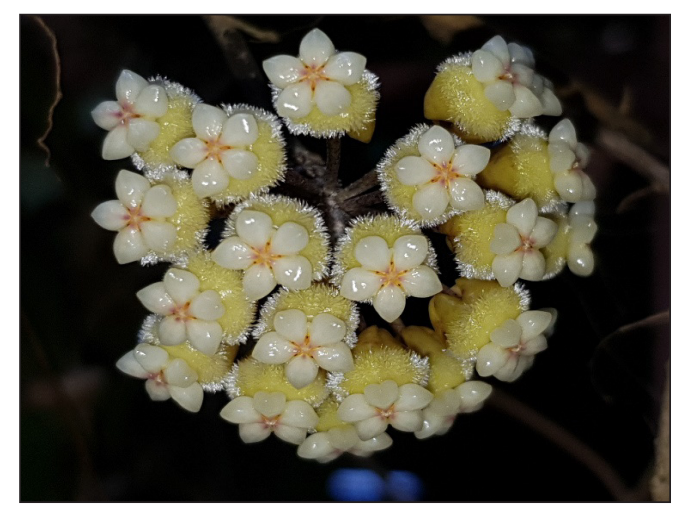

Figure 2. The inflorescence of Hoya peninsularis at the study sites 


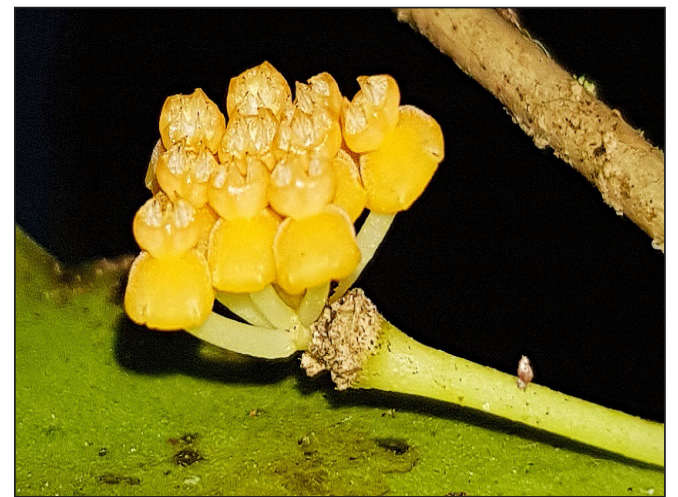

Figure 3. The inflorescence of Hoya ignorata at the study sites

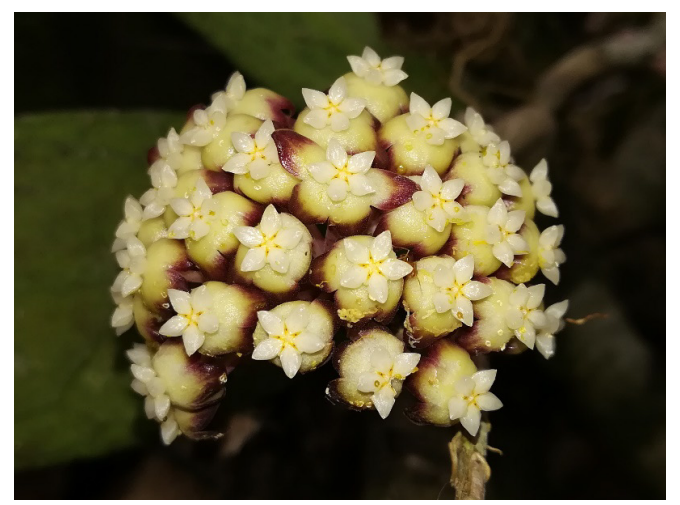

Figure 5. The inflorescence of Hoya finlaysonii at the study sites

parts of Thailand, are well distributed in the northern part of the peninsular, as this region is closer to Thailand (Rodda \& Simonsson, 2012; Trân et al., 2011; Wai et al., 2008).

The major factors that limit the distribution of epiphytes are light, water, and mineral nutrition (Benzing, 2008; Luttge, 2008). The majority of hoyas were found hanging on phorophytes near water stream or river, except a few of them, such as $H$. erythrina and $H$. verticillata, which grow on damp boulders and rocks. Although Hoya species mostly occur in areas with high

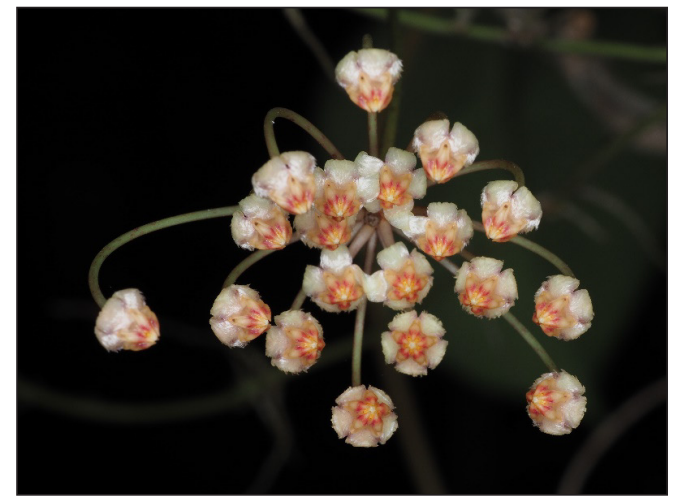

Figure 4. The inflorescence of Hoya revoluta at the study sites

humidity, it could be also be found in very dry habitats for extended periods (Rahayu, 2012). Habitat heterogeneity probably affects epiphyte distribution, whether it is seedling germination or recruitment success (Winkler et al., 2005). Through observation, no specific host plant selection for hoyas was found in this study. This finding is supported by previous studies stating that there is no particular association between hoyas and the host plants (Damayanti et al., 2017; Zakaria et al., 2019). Hoyas are observed to choose their host plants mainly for sunlight exposure.

It was observed that Sungai Rui had the highest number of Hoya species (21), the highest number of individuals (281), and the highest Shannon index $\left(H^{\prime}=2.741\right)$, followed by Lata Celak with 19 species of Hoya and Shannon index of 2.622 (Table $3)$. The higher Hoya diversity could be due to several factors that may be investigated in future studies. The lowest number of species (8) was recorded in Sedim and Bukit Hijau. These two studied sites are known as recreational forests with some degree of 
Table 3

The Hoya diversity indices of the study sites

\begin{tabular}{lccccccc}
\hline \multicolumn{1}{c}{ Parameters } & $\begin{array}{c}\text { Lata } \\
\text { Celak }\end{array}$ & Sedim & $\begin{array}{c}\text { Bukit } \\
\text { Hijau }\end{array}$ & Mahang & $\begin{array}{c}\text { Belukar } \\
\text { Semang }\end{array}$ & $\begin{array}{c}\text { Sungai } \\
\text { Rui }\end{array}$ & $\begin{array}{c}\text { Pondok } \\
\text { Tanjung }\end{array}$ \\
\hline No. of taxa $(S)$ & 19 & 8 & 8 & 10 & 10 & 21 & 13 \\
Individuals & 75 & 26 & 52 & 105 & 115 & 281 & 130 \\
Dominance $(D)$ & 0.09227 & 0.2012 & 0.2345 & 0.2472 & 0.1341 & 0.07575 & 0.1336 \\
Shannon $(H)$ & 2.622 & 1.778 & 1.669 & 1.688 & 2.097 & 2.741 & 2.243 \\
Evenness $e^{*} H / S$ & 0.7241 & 0.7399 & 0.6633 & 0.5409 & 0.8146 & 0.7385 & 0.7245 \\
\hline
\end{tabular}

human disturbances marked with logging and other activities (Rahmad \& Akomolafe, 2019). Hence, this might be responsible for the lower number of species and the lowest number of individuals of the species. Bukit Hijau and Mahang forests were observed to have the lowest diversity of Hoya species with Shannon index of 1.669 and 1.688, respectively. The same forests possessed the highest dominance index of 0.2345 and 0.2472 , respectively. This is very understandable because some species are expected to dominate the site with a lower diversity of plant species; hence, a higher dominance index is expected (Sasaki \&
Lauenroth, 2011). The highly diverse forests could be regarded as more functional and stable than the less diverse ones (Allan et al., 2011).

It is worthy to note that the Bukit Hijau and Mahang forests were the forests with the lowest species evenness index 0.6633 and 0.5409 , respectively. This could only suggest a direct relationship between Shannon index and evenness index because the sites with the lowest Shannon index also had the lowest evenness index; hence, rendered less productive (Allan et al., 2011). The rarefaction and extrapolation estimation of the species richness revealed

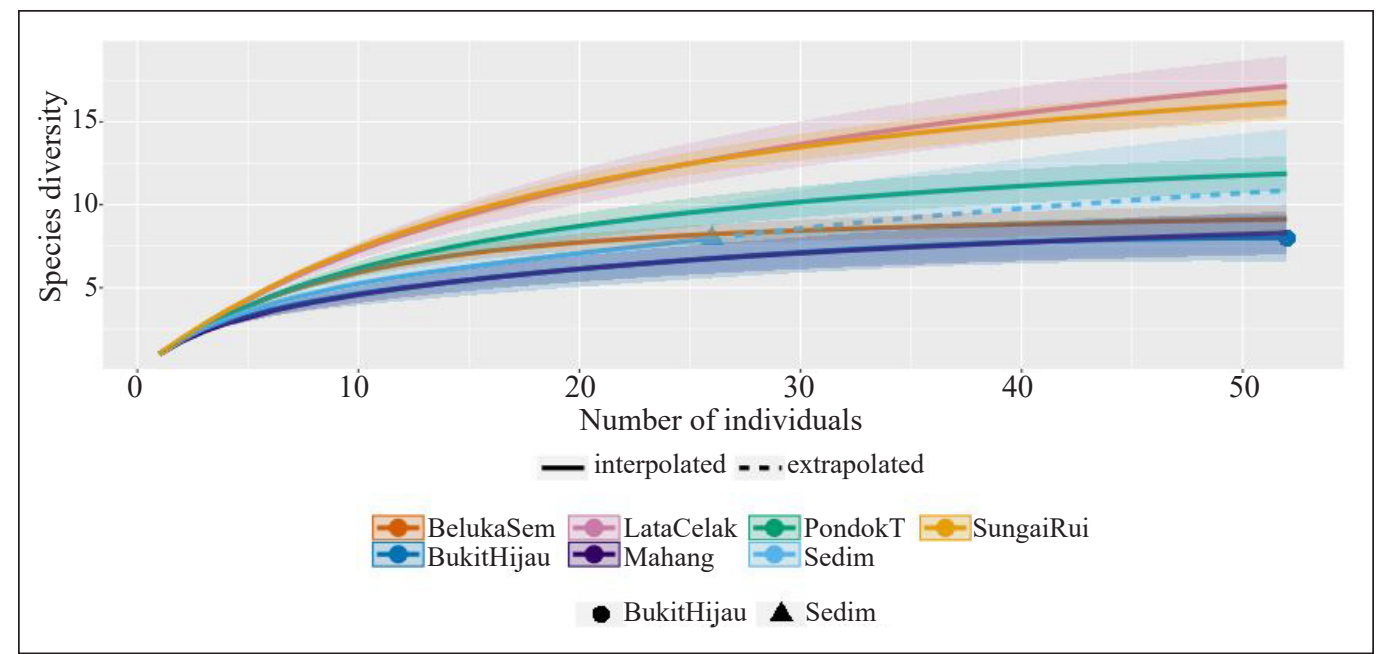

Figure 6. Sample-based rarefaction and extrapolation curve for the species richness of Hoya at the study sites 
that Sungai Rui and Lata Celak forests had the highest species richness. However, their differences are not significant based on the overlapped confidence intervals (Figure 6). However, their species richness is significantly different from the other forests. The low number of Sorenson similarity index (6.74\%) indicated the low similarities of Hoya species between the sampled sites.

\section{CONCLUSION}

This current checklist could be considered as a new and updated Hoya collection for northern Peninsular Malaysia. This study provided a view of the richness and diverse nature of the studied forests in terms of Hoya species, mainly in the northern area. More undiscovered or new species could be identified if a more comprehensive study was undertaken. The quantitative monitoring of Hoya diversity can provide fundamental understanding in detecting the changes in the species population. The results of this study can be useful in providing practical strategies for the conservation of Hoya species. Moreover, it is also important that the strategies are strictly implemented to protect forests that are essential for the survival and spread of this species.

\section{ACKNOWLEDGEMENT}

The authors would like to thank Universiti Sains Malaysia for providing study opportunity and staff assistance. The financial support of the project was provided under the Short Term Grant from Universiti Sains Malaysia (304/PBIOLOGI/6315202).

\section{REFERENCES}

Allan, E., Weisser, W., Weigelt, A., Roscher, C., Fischer, M., \& Hillebrand, H. (2011). More diverse plant communities have higher functioning over time due to turnover in complementary dominant species. Proceedings of the National Academy of Sciences, 108(41), 17034-17039. https://doi. org/10.1073/pnas.1104015108

Barukial, J., \& Sarmah, J. N. (2011). Ethnomedicinal plants used by the people of Golaghat District, Assam, India. International Journal of Medicinal and Aromatic Plants, 1(3), 203-211.

Benzing, D. H. (2008). Vascular epiphytes. Cambridge University Press.

Chao, A., Ma, K. H., \& Hsieh, T. C. (2016). iNEXT (iNterpolation and EXTrapolation) online: Software for interpolation and extrapolation of species diversity. https://chao.stat.nthu.edu.tw/ wordpress/sofware_download

Corbara, B., Dejean, A., \& Orivel, J. (1999). Ant gardens, a unique epiphyte-ant association. Année Biologique, 38, 73-89. https://doi.org/10.1016/ S0003-5017(99)80027-0

Damayanti, I., Siregar, I. Z., \& Rahayu, R. (2017). Asosiasi pohon dengan epifit Hoya spp. di Taman Nasional Bukit Duabelas [Tree association with epiphytes Hoya spp. in Bukit Duabelas National Park]. Journal of Tropical Silviculture, 8(3), 191-196.

Davidson, D. W., \& Epstein, W. W. (1989). Ephiphytic associations with ants. In U. Lüttge (Ed.), Vascular plants as epiphytes (pp. 200-233). Springer. https://doi.org/10.1007/978-3-64274465-5_8

Gautam, R. K., Singh, D., \& Nainwani, R. (2013). Medicinal plants having anti-arthritic potential: A review. International Journal of Pharmaceutical Sciences Review and Research, 19(1), 96-102.

Hammer, O., Harper, D. A., \& Ryan, P. D. (2001). PAST: Paleontological Statistics software 
package for education and data analysis. Paleontologia Electronica, 4(1), 9.

Hansen, D. M., Olesen, J. M., Mione, T., Johnson, S. D., \& Muller, C. B. (2007). Coloured nectar: distribution, ecology, and evolution of an enigmatic floral trait. Biological Reviews, 82(1), 83-111. https://doi.org/10.1111/j.1469185X.2006.00005.x

Kiew, R. (1989). Hoya endauensis (Asclepiadaceae) and Licuala dransfieldii (Palmae), two new species from Ulu Endau, Peninsular Malaysia. Malayan Nature Journal, 42(4), 262-265.

King, G., \& Gamble, J. S. (1908). Hoya - Materials for a flora of the Malayan Peninsula. Journal of the Asiatic Society of Bengal, 74, 559-580.

Kleijn, D., \& van Donkelaar, R. (2001). Notes on the taxonomy and ecology of the genus Hoya (Asclepiadaceae) in Central Sulawesi. Blumea, 46(3), 457-483.

Lamb, A., \& Rodda, M. (2016). A guide to hoyas of Borneo. Natural History Publications (Borneo).

Luttge, U. (2008). Physiological ecology of tropical plants (2nd ed.). Springer. Where

Mollik, M. A. H., Hossan, M. S., Paul, A. K., TaufiqUr-Rahman, M., Jahan, R., \& Rahmatullah, M. (2010). A comparative analysis of medicinal plants used by folk medicinal healers in three districts of Bangladesh and inquiry as to mode of selection of medicinal plants. Ethnobotany Research and Applications, 8, 195-218. https:// doi.org/10.17348/era.8.0.195-218

Orivel, J., \& Leroy, C. (2011). The diversity and ecology of ant gardens (Hymenoptera: Formicidae; Spermatophyta: Angiospermae). Myrmecological News, 14, 73-85.

Rahayu, S. (2012). Hoya (Apocynaceae: Asclepiadoideae) diversity in Gunung Gede Pangrango National Park, West Java, Indonesia.
Reinwardtia, 13(4), 331-339. https://doi. org/10.14203/reinwardtia.v13i4.436

Rahayu, S., Fakhrurrozi, Y., \& Putra, H. F. (2018). Hoya species of Belitung Island, Indonesia, utilization and conservation. Biodiversitas Journal of Biological Diversity, 19(2), 369-376. https://doi.org/10.13057/biodiv/d190203.

Rahayu, S., Jusuf, M., Suharsono, S., Kusmana, C., \& Abdulhadi, R. (2010). Morphological variation of Hoya multiflora Blume at different habitat type of Bodogol Research Station of Gunung Gede Pangrango National Park, Indonesia. Biodiversitas Journal of Biological Diversity, 11(4), 187-193. https://doi. org/10.13057/biodiv/d110404

Rahmad, Z., \& Akomolafe, G. F. (2019). Taxonomic diversity of ferns of two recreational forests in Kedah, Malaysia. Malaysian Journal of Science, 38(3), 1-11. https://doi.org/10.22452/ mjs.vol38no3.1

Ridley, H. N. (1923). A botanical excursion to northern Sumatra. Journal of the Malayan Branch of the Royal Asiatic Society, 1(87), 46-113.

Rintz, R. E. (1978). The Peninsular Malaysian species of Hoya (Asclepiadaceae). Malaysian Nature Journal, 30(3\&4), 467-522.

Rintz, R. E. (1980). The Peninsular Malayan species of Dischidia. Blumea, 26(1), 81-126.

Rodda, M. (2015). Two new species of Hoya R.Br. (Apocynaceae, Asclepiadoideae) from Borneo. PhytoKeys, 53, 83-93. https://doi.org/10.3897/ phytokeys.53.5079

Rodda, M., \& Simonsson, J. N. (2012). (Apocynaceae, Asclepiadoideae), a new campanulate flowered species from Peninsular Malaysia and southern Thailand. Feddes Repertorium, 122(5-6), 337343. https://doi.org/10.1002/fedr.201100019

Rodda, M., \& Simonsson, J. N. (2013). The taxonomy of Hoya micrantha and Hoya revoluta 
(Apocynaceae, Asclepiadoideae). Webbia, 68(1), 7-16. https://doi.org/10.1080/00837792.2013. 802937

Rodda, M., \& Zakaria, R. (2020). Hoya peninsularis (Apocynaceae, Asclepiadoideae), a new species from Peninsular Malaysia, and notes on Hoya maingayi and Gongronema wrayi. Nordic Journal of Botany, 38(10). https://doi. org/10.1111/njb.02854

Salim, J. M., \& Nikong, D. (2020). Notes on Hoya of Terengganu, Peninsular Malaysia. Malayan Nature Journal, 72(1), 43-51.

Sasaki, T., \& Lauenroth, W. K. (2011). Dominant species, rather than diversity, regulates temporal stability of plant communities. Oecologia, 166(3), 761-768. https://doi.org/10.1007/s00442-0111916-1

Sorenson, T. (1948). A method of establishing groups of equal amplitude in plant sociology based on similarity of species content and its application to analyses of the vegetation on Danish commons. Biologiske Skrifter, 5(4), 1-34.

Sulaeman, M., Sulistijorini, S., \& Rahayu, S. (2019). Habitat suitability for Hoya spp. (Apocynaceae) in the Bodogol Conservation Area, West Java. Biosaintifika: Journal of Biology and Biology Education, 11(1), 91-99. https://oi. org/10.15294/biosaintifika.v11i1.13021

Trân, T. B., Kim, J. H., Kim, D. K., Lee, J., Bui, T. H., Simonsson, J. N., \& Rodda, M. (2011). Hoya ignorata (Apocynaceae, Asclepiadoideae): An overlooked species widely distributed across South East Asia. Novon, 21(4), 508-514. https:// doi.org/10.3417/2010068

Wagner, D. (1997). The influence of ant nests on Acacia seed production, herbivory and soil nutrients. Journal of Ecology, 85(1), 83-93. https://doi.org/10.2307/2960629
Wai, J. S., Sridith, K., \& Thaithong, O. (2008). Hoya imperialis Lindl. (Apocynaceae: Asclepiadaceae), a new record for Thailand. Thai Forest Bulletin (Botany), (36), 81-85.https:// li01.tci-thaijo.org/index.php/ThaiForestBulletin/ article/view/24184

Wanntorp, L. (2009). Phylogenetic systematics of Hoya (Apocynaceae). Blumea-Biodiversity, Evolution and Biogeography of Plants, 54(1-3), 228-232. https://doi.org/10.3767/000651909X476201

Wanntorp, L., \& Kunze, H. (2009). Identifying synapomorphies in the flowers of Hoya and Dischidia - Toward phylogenetic understanding. International Journal of Plant Sciences, 170(3), 331-342. https://doi. org/10.1086/596329

Wanntorp, L., Kocyan, A., van Donkelaar, R., \& Renner, S. S. (2006). Towards a monophyletic Hoya (Marsdenieae, Apocynaceae): Inferences from the chloroplast $\operatorname{trn} L$ region and the $r b c L$ atpB spacer. Systematic Botany, 31(3), 586-596. https://doi.org/10.1600/036364406778388593

Winkler, M., Hulber, K., \& Hietz, P. (2005). Effect of canopy position on germination and seedling survival of epiphytic bromeliads in a humid montane forest. Annals of Botany, 95(6), 10391047. https://doi.org/10.1093/aob/mci115

Yang, D. S., Pennisi, S. V., Son, K. C., \& Kaysl, S. J. (2009). Screening indoor plants for volatile organic pollutant removal efficiency. Hortscience, 44(5), 1377-1381. https://doi. org/10.21273/HORTSCI.44.5.1377

Zakaria, R., Mansor, A., Syafiq, M., Azmi, A., Rusdi, N. M., Harun, A. H., Harun, M. S., \& Azmi, M. F. (2019). Notes on the Hoya (Apocynaceae, Asclepiadoideae) of Pulau Pangkor, Perak, Peninsular Malaysia. The Malaysian Forester, 82(1), 197-203. 
